\title{
KAJIAN RISIKO BENCANA LONGSOR KECAMATAN LOANO KABUPATEN PURWOREJO
}

\section{LANDSLIDE DISASTER RISK ANALYSIS IN LOANO DISTRICT, PURWOREJO REGENCY}

\author{
Retno Widiastutik', Imam Buchori ${ }^{2}$ \\ 'Badan Penanggulangan Bencana Daerah Prov Jawa Tengah; Jl. Imam Bonjol 1F Semarang; widiastutik.retno.marijo@gmail.com \\ 2Departemen Perencanaan Wilayah dan Kota; Universitas Diponegoro, Semarang, Jawa Tengah; i.buchori@undip.ac.id
}

\section{Info Artikel:}

- Artikel Masuk: 17/06/18

- Artikel diterima: 09/07/18

- Tersedia Online: $24 / 08 / 18$

\begin{abstract}
ABSTRAK
Kecamatan Loano berada di bagian timur-selatan Kabupaten Purworejo, merupakan daerah rawan longsor yang disertai kondisi sosial ekonomi yang menambah kerentanannya. Studi ini bertujuan untuk mengkaji risiko bencana longsor, cakupan kajian meliputi karakteristik ancaman, kerentanan \{sosial ekonomi \& fisik lingkungan, kapasitas (respon lingkungan)\} serta risiko bencana. Pengolahan data menggunakan software ArcGIS dan SPSS. Secara fisik alam, ancaman risiko longsor bervariasi yaitu $21,36 \mathrm{~km}^{2}(40,09 \%)$ indeks rendah, $13.14 \mathrm{~km}^{2}(24,66 \%)$ sedang dan $18,78 \mathrm{~km}^{2}(35,25 \%)$ tinggi. Indeks kerentanan sosial ekonomi \& fisik lingkungan terdiri dari 3 desa indeks rendah, 11 desa sedang dan 7 desa tinggi. Karakteristik kapasitas (respon lingkungan) diambil dengan menggunakan kuesioner individu masyarakat dan pemerintah desa. Karakteristik kapasitas (respon lingkugan)-nya adalah 14 desa indeks rendah, 4 desa sedang dan 3 desa tinggi. Kerentanan secara holistickyang merupakan jumlah total kerentanan sosial ekonomi \& fisik lingkungan serta kapasitas (respon lingkungan) terdapat 3 desa indeks rendah, 4 desa sedang dan 14 desa tinggi. Tingkat risiko bencana longsor bervariasi, terdiri dari rendah $6,72 \mathrm{~km}^{2}(12,62 \%)$, sedang $24,59 \mathrm{~km}^{2}(46,15 \%)$ hingga tinggi $21,96 \mathrm{~km}^{2}(41,23 \%)$. Risiko longsor yang tinggi perlu dikurangi dengan menurunkan kerentananya. Selanjutnya, diharapkan metode ini dapat diterapkan di wilayah lainnya yang memiliki karakteristik hampir sama dengan Kecamatan Loano.

Kata Kunci : longsor, risiko bencana, ancaman, kerentanan, kapasitas (respon lingkungan)
\end{abstract}

\section{ABSTRACT}

Subdistrict Loano located in the southern-east part of Purworejo District is an areas prone to landslides accompanied by socio economic conditions that add its vulnerability. The study aims to assess the risk of landslide disaster, the scope of the risk assessment consists of the threat characteristics, vulnerability \{ (socio economic \& physical environment vulnerability, capacity (response)\} dan landslide risk. Using ArcGIS and SPSS 18 software to processing some data. Physically, the hazard of landslide risk varies from $21,36 \mathrm{~km}^{2}$ (40,09\%) to low index, $13,14 \mathrm{~km}^{2}(24,66 \%)$ medium and $18,78 \mathrm{~km}^{2}(35,25 \%)$ high. The socio economic and physical environmental physical vulnerability consist of 3 low index villages, 11 medium and 7 high. Capacity (response) index taken using a questionnaire of individual sample communities and 21 village government employee samples. Capacity (response) characterictics are 14 high index villages, 4 medium and 3 low. The holistic vulnerability index, which is the total number of socio economic \& physical environment and capacity (response), there are 3 low index villages, 4 villages, and 14 high villages. Landslide risk level is varied, consisting of $6,72 \mathrm{~km}^{2}$ (12,62\%) low index, 24,59 km ${ }^{2}(46,15 \%)$ medium and $21,96 \mathrm{~km}^{2}$ (41,23\%) high. The high risk of landslide needs to be reduced by decreasing tne vulnerability. Furthermore, the expected of this landslide risk assessment method can be applied in other areas that have characteristics similar to Loano Subdistrict characteristic.

Keyword: landslide, disaster risk, threat, vulnerability, capacity (response)

Copyright $\odot 2018$ JPWK-UNDIP This open access article is distributed under a Creative Commons Attribution (CC-BY-NC-SA) 4.0 International license.

Cara men-sitasi (APA 6th Style):

Widiastutik, Retno \& Buchori, Imam. (2018). Kajian Risiko Bencana Longsor Kecamatan Loano Kabupaten Purworejo. Jurnal Pembangunan Wilayah dan Kota, Vol 14 (2), 109- 122 


\section{PENDAHULUAN}

Hanya selama setengah dekade pada abad ke-21, banyak kejadian bencana yang mencengangkan di seluruh dunia yang tidak ditemukan pada abad sebelumnya (Pinkowski, 2008). Indonesia juga mengalami kenaikan jumlah kejadian bencana yang diikuti oleh dampak korban, kerusakan dan kerugian yang tidak sedikit, diantaranya longsor. Sepuluh tahun terakhir (tahun 2006-2016), kejadian longsor menyumbang 18,1\% dari total kejadian bencana di Indonesia, dengan jumlah korban meninggal 10,8\% (BNPB, 2017). Longsor merupakan gerakan massa (mass movement) berupa tanah, batu, timbunan atau material campuran lainnya, terjadi di sepanjang bidang longsor kritis, terjadi apabila gaya penahan longsor lebih kecil dibandingkan gaya pendorongnya (Hardiatmo, 2012). Penyebab utama terjadinya longsor di Indonesia adalah perpaduan kondisi geologi, bentuk lahan pegunungan, penggunaan lahan serta kerentanan sosial yang tinggi pada masyarakat yang cenderung hidup di area longsor (Karnawati, Fathani, Andayani, Burton, \& Sudarno, 2009). Gariano \& Guzzetti (2016) menambahkan bahwa pemanasan global berakibat pada meningkatkan frekuensi dan intensitas hujan. Intensitas hujan dapat memicu kejadian longsor. Begitu juga Indonesia yang beriklim tropis yang selalu mendapatkan hujan di setiap tahun. Ditambah dengan dilintasinya jalur penunjaman lempeng yaitu pertemuan lempeng Eurasia, Pasifik dan Australia yang sering menimbulkan getaran gempa (Karnawati, 2005). Menurut Gariano \& Guzzetti (2016) gempa merupakan salah satu pemicu longsor. Upaya antisipasi/mitigasi dan persiapan mengurangi dampak kerugian longsor suatu wilayah sehingga wilayah tersebut disebut resillience menjadi tempat tinggal yang inklusif, aman, tahan serta berkelanjutan dapat dilakukan sebelum longsor (Shari \& Yamagata, 2016). Upaya ini disebut Fatemi, Ardalan, Aguirre, Mansouri, \& Mohammadfam (2017) sebagai respon lingkungan yang dapat mengurangi kerentanan. Cotecchia et al. (2016) juga sepakat bahwa karakteristik risiko longsor harus diteliti dan dikembangkan dalam berbagai skala. Kebutuhan pemetaan risiko longsor pada tingkat lokal atau detail sangat diperlukan. Risiko (longsor) adalah fungsi senyawa ancaman alam dan kelompok orang, karakteristik kerentanan yang bervariasi pada ancaman yang spesifik, yang menempati ruang dan waktu (Wisner, 2004; dalam Frigerio\& De Amicis, 2016). Hasil kajian risiko longsor dapat digunakan untuk memberikan masukan kepada pembuat kebijakan dan stakeholder lainnya dalam melakukan perencanaan wilayah dan pengambilan keputusan.

Kabupaten Purworejo terdiri dari 2 karakteristik bentang lahan yaitu pegunungan/perbukitan dan dataran. Bentang lahan pegunungan/perbukitan merupakan daerah rawan longsor serta lokasi tidak jauh dengan jalur penunjaman lempeng, adanya struktur patahan yang berkembang menjadi zona lemah gerakan masa, geomorfologi lereng tajam, curah hujan tinggi dan pilihan penggunaan lahan (Bemmelen, V., 1949; Karnawati, 2005; DPU dan Penataan Ruang Kab. Purworejo, 2017). Salah satu kecamatan tersebut adalah Kecamatan Loano yang berlokasi di bagian timur-selatan Kabupaten Purworejo. Pada pertengahan tahun 2016, banyak longsor yang terjadi di Kabupaten Purworejo yang menyebabkan banyak korban meninggal dan dampak lainnya, termasuk Kecamatan Loano (BPBD Prov Jateng, 2016). Risiko longsor ini termasuk dalam kategori tingkat mayor (Coppola, 2006). Penduduk Kecamatan Loano sesuai dengan data Badan Pusat Statistik (BPS) pada tahun 2016 sebanyak 35.401 jiwa tersebar di 21 desa. Menurut observasi lapangan diantaranya tinggal di lereng yang curam bahkan mengeruk kaki lerengnya untuk dijadikan tempat tinggal, sehingga kerentanan bangunannya tinggi. Ada korelasi antara aktivitas kegagalan lereng dengan kontruksi Ayalew \& Yamagishi (2005) dalam Kiyoung \& Kim (2018). Menurut data BPS (2016) $46,34 \%$ penduduk tidak/belum bekerja (bekerja dalam sektor informal). Diantaranya menggantungkan sumber pendapatannya pada sumberdaya alam, ini akan lebih rentan jika terjadi bencana karena penduduk akan kehilangan pekerjaan (Cutter, Boruff, \& Shirley, 2003). Selain itu, ada sekitar 37\% keluarga kurang sejahtera (Bappeda Purworejo, 2015). Kondisi sosial ekonomi ini menambah kerentanan wilayah disamping ancaman alamnya. Saat ini diperlukan informasi mengenai kajian risiko bencana longsor dengan ketajaman informasi yang tinggi, sehingga akan mampu menjawab bagaimana tingkat dan sebaran keruangan risiko longsor, ancaman, kerentanan dan respon yang telah dilakukan. Kajian ini merupakan salah satu bagian dari tindakan preventif atau mitigasi bencana. Hasil kajian risiko dapat digunakan sebagai masukan informasi untuk mengurangi risiko bencana longsor. 


\section{DATA DAN METODE}

Penelitian ini merupakan penelitian terapan (applied research) dengan pendekatan kuantitatif. Pengolahan data menggunakan bantuan software ArcGIS dan SPSS. Data yang digunakan berupa data primer dan sekunder, didukung pengamatan lapangan untuk menambah deskripsi kuantitatif. Analisis meliputi nilai indeks dan sebaran keruangan, yang terdiri dari:

2.1. Analisis Karakteristik Ancaman Longsor

Analisis dilakukan dengan menggunakan indeks ancaman longsor hasil skoring dan overlay variabel penyebab longsor dengan sistem pengkelasan Natural Break (Jenks), dikelaskan menjadi 3 indeks, yaitu: rendah, sedang dan tinggi.

Tabel 1. Bobot Faktor Penentu Ancaman Longsor Metode Determistik (Modifikasi dari BNPB, 2016); Raghunvanshi et al., 2014; Arsyad, 1989 dan Palladino et al., 2017)

\begin{tabular}{|c|c|c|c|}
\hline $\begin{array}{l}\text { Penyebab } \\
\text { Longsor }\end{array}$ & Variabel/Bobot & Kelas & Nilai \\
\hline \multirow{15}{*}{$\begin{array}{l}\text { Variabel Intrinsik } \\
\text { (Pengontrol) }\end{array}$} & \multirow[t]{5}{*}{ Kemiringan Lereng/ 2} & Sangat sedikit curam (very gentle slope) & $<15^{\circ}$ \\
\hline & & Sedikit Curam (gentle slope) & $16-25^{\circ}$ \\
\hline & & Curam sedang (moderately steep slope) & $26-35^{\circ}$ \\
\hline & & Curam (steep slope) & $36-45^{\circ}$ \\
\hline & & Jurang (escarpment/cliff) & $>45^{\circ}$ \\
\hline & \multirow{3}{*}{$\begin{array}{l}\text { Tipe Batuan (Struktur } \\
\text { geologi)/1 }\end{array}$} & Batuan Aluvial & \\
\hline & & Batuan Sedimen & \\
\hline & & Batuan Vulkanik & \\
\hline & \multirow{3}{*}{$\begin{array}{l}\text { Tipe Tanah (tekstur } \\
\text { tanah)/1 }\end{array}$} & Berpasir & \\
\hline & & Berliat - Berpasir & \\
\hline & & Berliat & \\
\hline & \multirow{4}{*}{$\begin{array}{l}\text { Kedalaman Tanah (Solum } \\
\text { tanah)/1 }\end{array}$} & Sangat Dangkal & $<25 \mathrm{~cm}$ \\
\hline & & Dangkal & $25-50 \mathrm{~cm}$ \\
\hline & & Sedang & $50-90 \mathrm{~cm}$ \\
\hline & & Dalam & $>90 \mathrm{~cm}$ \\
\hline \multirow{6}{*}{$\begin{array}{l}\text { Variabel } \\
\text { Ekstrinsik } \\
\text { (Pemicu) }\end{array}$} & \multirow[t]{6}{*}{ Curah hujan/1,5 } & Sangat rendah (very low) & $0-500 \mathrm{~mm}$ \\
\hline & & Rendah (low) & $501-1000 \mathrm{~mm}$ \\
\hline & & Sedang (medium) & $1001-1500 \mathrm{~mm}$ \\
\hline & & Sedang - tinggi (medium-high) & $1501-2000 \mathrm{~mm}$ \\
\hline & & Tinggi (high) & $2001-2500 \mathrm{~mm}$ \\
\hline & & Sangat tinggi (very high) & $2501-3000 \mathrm{~mm}$ \\
\hline
\end{tabular}

\subsection{Analisis Karakteristik Kerentanan}

Analisis karakteristik kerentanan meliputi kerentanan sosial ekonomi, fisik lingkungan, kapasitas (respon lingkungan) dan karentanan total. Adapun variabel penyusun kerentanan sosial ekonomi dan fisik lingkungan dalam Tabel 2. Persamaan untuk menghitung perpaduan antara kerentanan sosial ekonomi dan fisik lingkungan adalah Indeks Kerentanan Sosial Ekonomi dan Fisik Lingkungan $=[\{$ (indeks kerentanan sosial ekonomi) + (indeks keretanan fisik lingkungan)\}/2] (Modifikasi dari Shariful et al, 2013).

Tabel 2. Variabel Kerentanan Sosial Ekonomi dan Fisik Lingkungan (Modifikasi dari BNPB, 2012; Shariful, Shahidul, \& Swapan, 2013; Xiaoyan \& Xiaofei, 2012); Cutter et al., 2003; Fatemi et al., 2017; Kwabena et al., 2015)

\begin{tabular}{llll}
\hline Jenis Kerentanan & \multicolumn{1}{c}{ Variabel } & \multicolumn{1}{c}{ Kelas } & Nilai \\
\hline $\begin{array}{l}\text { Kerentanan Sosial } \\
\text { Ekonomi }\end{array}$ & Kepadatan Penduduk & Rendah (Low) & $<500$ jiwa $/ \mathrm{km}^{2}$ \\
\cline { 3 - 4 } & & Sedang (medium) & $500-700$ jiwa $/ \mathrm{km}^{2}$ \\
\hline
\end{tabular}




\begin{tabular}{|c|c|c|c|}
\hline Jenis Kerentanan & Variabel & Kelas & Nilai \\
\hline & & Tinggi (high) & $>700 \mathrm{jiwa} / \mathrm{km}^{2}$ \\
\hline & \multirow{3}{*}{$\begin{array}{l}\text { Jenis Kelamin (Rasio jenis kelamin } \\
\text { perempuan) }\end{array}$} & Rendah (Low) & $0-20 \%$ \\
\hline & & Sedang (medium) & $20-40 \%$ \\
\hline & & Tinggi (high) & $>40 \%$ \\
\hline & \multirow[t]{3}{*}{ Keluarga Kurang Sejahtera } & Rendah (low) & $0-20 \%$ \\
\hline & & Sedang (medium) & $20-40 \%$ \\
\hline & & Tinggi (high) & $>40 \%$ \\
\hline & \multirow[t]{3}{*}{ Penyandang Disabilitas } & Rendah (low) & $0-5 \%$ \\
\hline & & Sedang (medium) & $5-10 \%$ \\
\hline & & Tinggi (high) & $>10 \%$ \\
\hline & \multirow{3}{*}{$\begin{array}{l}\text { Kelompok Umur Rentan (umur } 5 \\
\text { tahun dan }>65 \text { tahun) }\end{array}$} & Rendah (low) & $0-20 \%$ \\
\hline & & Sedang (medium) & $20-40 \%$ \\
\hline & & Tinggi (high) & $>40 \%$ \\
\hline & \multirow[t]{3}{*}{ Tingkat Pendidikan Rendah } & Rendah (low) & $0-30 \%$ \\
\hline & & Sedang (medium) & $30-50 \%$ \\
\hline & & Tinggi (high) & $30-50 \%$ \\
\hline \multirow{6}{*}{$\begin{array}{l}\text { Kerentanan Fisik } \\
\text { dan Lingkungan }\end{array}$} & \multirow{3}{*}{$\begin{array}{l}\text { Penggunaan Lahan (Berkaitan } \\
\text { dengan mata pencaharian informal) }\end{array}$} & Rendah (low) & \\
\hline & & Sedang (medium) & \\
\hline & & Tinggi (high) & Kelas Nilai Variabel $=$ \\
\hline & \multirow{3}{*}{$\begin{array}{l}\text { Fasilitas umum (Infrastruktur } \\
\text { Publik): Puskesmas/Pustu, Sekolah, } \\
\text { Pasar/Kios/Bank }\end{array}$} & Rendah (low) & $\underline{\text { Nilai tertinggi - nilai terendah }}$ \\
\hline & & Sedang (medium) & Jumlah kelas interval \\
\hline & & Tinggi (high) & \\
\hline
\end{tabular}

Data untuk analisis kapasitas (respon lingkungan) diperoleh dengan menggunakan kuesioner, tipe skala data Guttman sebanyak 345 sampel individu masyarakat dan 21 pegawai pemerintah desa. Kuesioner individu masyarakat untuk variabel: (1) pengetahuan individu tentang ancaman longsor, (2) kemampuan ekonomi masyarakat dalam menghadapi bencana, (3) akses keputusan penggunaan lahan bangunan, (4) kelembagaan komunitas internal masyarakat, (5) hubungan komunitas dengan stakeholder luar. Diolah dengan menggunakan software SPSS metode cluster Non-hirarki (K-Means). Sampel kuesioner diambil dengan metode probability random sampling berdasar jumlah penduduk per-desa. Baik kuesioner individu masyakarat dan pemerintah diuji validitas dan reabilitasnya.

Tabel 3. Pengkelasan Desa Menurut Indeks Kapasitas Masyarakat (Diadopsi dari Kwabena et al., 2015)

\begin{tabular}{lll} 
& \multicolumn{1}{c}{$\begin{array}{c}\text { Jumlah Individu Masyarakat } \\
\text { Kapasitas Tinggi }\end{array}$} & Tingkat \\
\hline$<33 \%$ & Individu Masyarakat Desa Berkapasitas Tinggi & Rendah \\
\hline $33-67 \%$ & Individu Masyarakat Desa Berkapasitas Tinggi & Sedang \\
\hline$>67 \%$ & Individu Masyarakat Desa Berkapasitas Tinggi & Tinggi \\
\hline
\end{tabular}

Sampel kuesioner pemerintah desa untuk memperoleh variabel: (1) akses penggunaan lahan, (2) hubungan antara instasi BPBD Kabupaten Purworejo dengan pemerintah desa serta kebijakan, (3) anggaran dan panduan mengenai longsor. Data diolah dengan software SPSS metode cluster Hirarki (Ward's Methods), diklafisikasikan dalam kelas rendah, sedang dan tinggi berdasarkan kemiripan jawaban. Perpaduan antara indeks kapasitas individu masyarakat dan pemerintah desa merupakan indeks kapasitas (respon lingkungan) per-desa. Matrik perpaduan indeks kapasitas individu masyarakat dan pemerintah desa pada Gambar 1.

Kerentanan total atau secara holistic meliputi perpaduan antara kerentanan sosial ekonomi dan fisik lingkungan serta kapasitas (respon lingkungan) dengan persamaan: Indeks Kerentanan $=[0,500$ 
\{(Kerentanan Ekonomi Sosial dan Fisik Lingkungan) + (Kapasitas (Respon Lingkungan))\}] (Diadopsi dari Almeida et al., 2016). Yang kemudian diolah dengan matrik sebagaimana Gambar 1.
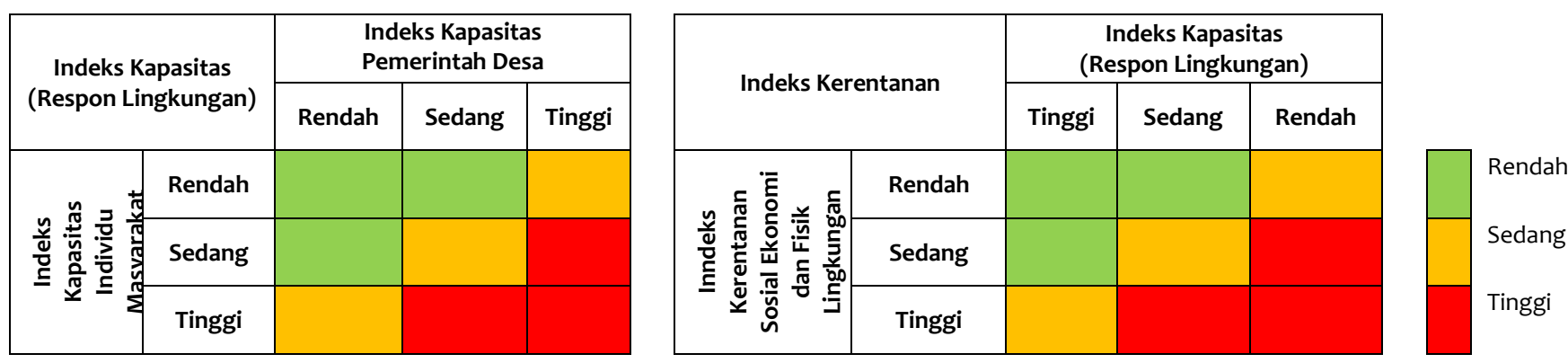

Gambar 1. Matrik Penentuan Indeks Kapasitas (Respon Lingkungan) Dan Kerentanan

(Diadopsi dari BNPB, 2012 ; Xiaoyan \& Xiaofei, 2012)

\subsection{Analisis Risiko Bencana Longsor}

Analisis risiko bencana longsor meliputi tingkat dan sebaran keruangan berdasar pada peta tingkat risiko longsor. Persamaan risiko longsor yang digunakan adalah $\mathrm{R}=\mathrm{H} \times \mathrm{V}$ (Xiaoyan \& Xiaofei, 2012). Dimana: R (Risk) merupakan ancaman, dan V (Vulnerability) merupakan kerentanan. Persamaan tersebut diterima secara umum (Xiaoyan \& Xiaofei, 2012). Dari persamaan tersebut, hubungan antara ancaman dan kerentanan diolah dengan menggunakan matrik risiko Gambar 2.
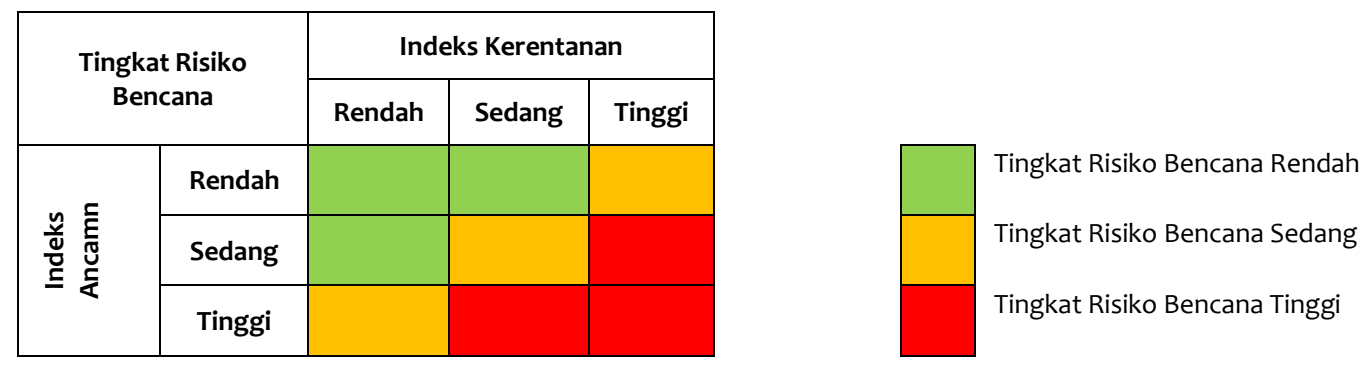

Gambar 2. Matrik Penentuan Tingkat Risiko Longsor (Modifikasi dari Xiaoyan \& Xiaofei, 2012)

\section{HASIL DAN PEMBAHASAN}

\subsection{Karakteristik ancaman longsor}

Dari hasil overlay variabel ancaman longsor dihasilkan $21,36 \mathrm{~km}^{2}$ (40,09\%) indeks ancaman rendah, $13.14 \mathrm{~km}^{2}(24,66 \%)$ sedang dan $18,78 \mathrm{~km}^{2}(35,25 \%)$ tinggi. Sebaran spasial indeks ancaman sebagaimana Gambar 3. Secara spasial, daerah di sebelah timur mempunyai indek ancaman longsor lebih tinggi dibandingkan dengan sebelah barat, yaitu pada indeks sedang-tinggi. Pada umumnya, desa memiliki prosentase luas indeks sedang-tinggi lebih banyak daripada indeks rendah. Karakteritik daerah bagian timur adalah kemiringan lereng umumnya $>15 \%$, curah hujan tahunan sangat tinggi. Lebih tinggi dibandingkan bagian barat, beberapa daerah mempunyai formasi batuan beku (andesit). Seperti yang kita ketahui batuan andesit dapat berfungsi menjadi bidang gelincir jika terjadi ketidakstabilan lereng. Hampir semua daerah dengan kemiringan lereng $<15 \%$ mempunyai indeks ancaman longsor rendah. Kecuali di beberapa daerah, seperti di Desa Tridadi, Banyuasin Separe, Sedayu dan Ngargosari, walaupun kemiringan lerengnya $<15 \%$, namun indeks ancamannya tinggi karena curah hujan yang tinggi dan dukungan variabel longsor lainnya. Berkebalikan dengan beberapa area di Desa Kemejing, Tepansari, Kalikalong dan Rimun walau tidak mempunyai curah hujan yang tinggi namun karena memiliki kemiringan lereng lebih terjal, sehingga mempunyai indeks tinggi. 


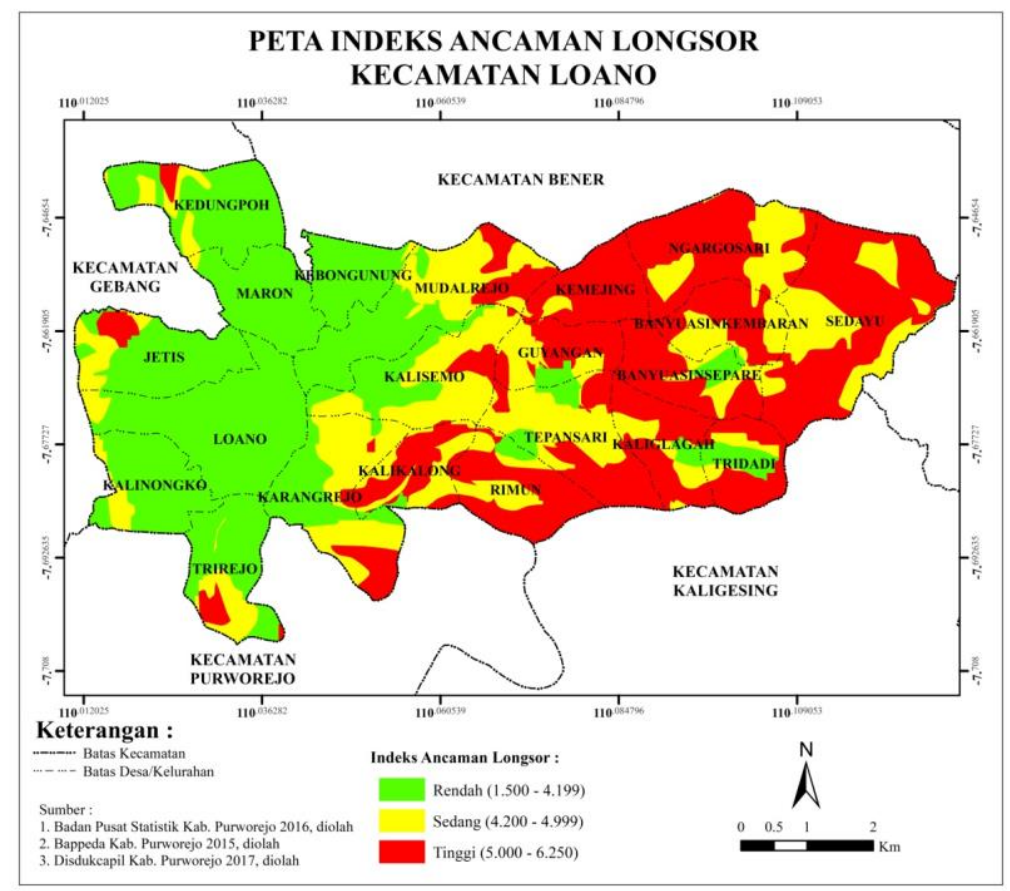

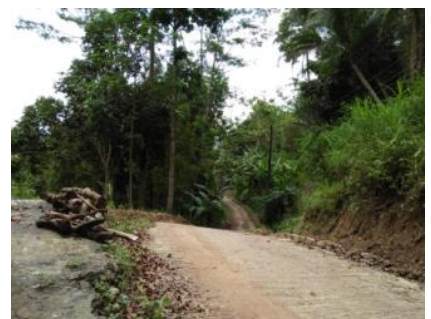

Retakan tanah di Dusun Kapuan Desa Ngargosari sejak \pm tahun 1990 .

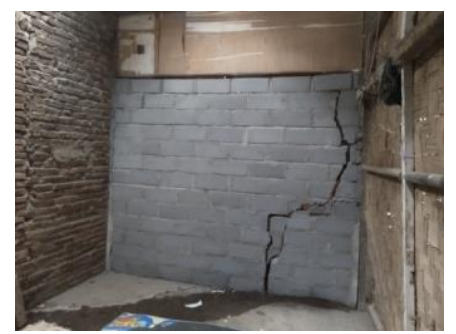

Rekahan dalam rumah penduduk yang ditimbun tanah

Gambar 3. Peta Indeks Ancaman Longsor Kecamatan Loano Dan Rekahan Tanah Di Lapangan (Pengolahan Data, 2018; Observasi Lapangan, 2017)

Area sebelah barat yang mempunyai indeks ancaman longsor rendah, disusun oleh faktor penentu ancaman longsor antara lain kemiringan lereng $<15 \%$, curah hujan tahunan tingkat tinggi (2001-2500 mm) lebih rendah daripada bagian timur, formasi geologi alluvium sehingga skor faktor penentu untuk ancaman ini kecil, meskipun disusun oleh ketebalan solum tanah yang dalam $(>120 \mathrm{~cm})$. Sebagian kecil area yang ada di sebelah barat yang berindeks ancaman tinggi, ditemukan rekahan yang dalam dan lebar di area ini, bahkan retakan tersebut berada di dalam rumah, yaitu di Dusun Bandingan Desa Kedungpoh dan Dusun Gunung Tumpeng Desa Jetis. Apabila terpicu hujan akan menyebabkan dampak yang fatal bagi penghuninya bagi area dibawahnya. Beberapa area Desa Kedungpoh bersebelahan atau satu bukit dengan Desa Penungkulan yang rawan longsor. Sementara variabel tekstur tanah, hampir semua mempunyai tektur tanah berliat/lempung, sehingga mempunyai pengaruh kelas 3 dalam penentuan indeks ancaman longsor. Dengan diketahui kondisi indeks ancaman longsornya, bisa memberikan masukan kepada masyarakat, pemerintah dan stakeholder lainnya dalam melakukan pemanfaatan lahan dan beradaptasi dengan lingkungan di area rawan longsor.

\subsection{Karakteristik Kerentanan}

\subsubsection{Karakteristik Kerentanan Sosial Ekonomi}

Kelas skor pengolahan data kerentanan sosial ekonomi dan sebaran spasial indeks penduduk terpapar pada Gambar 4. Terdapat 4 desa dengan kelas indeks kerentanan sosial ekonomi tinggi, 10 desa sedang, dan 7 desa rendah. Setiap desa mempunyai rasio jenis kelamin yang sama, yaitu jumlah penduduk perempuan $>40 \%$. Ini menyebabkan desa menjadi rentan apabila terjadi bencana dikarenakan karakteristik yang dimiliki perempuan. Setiap desa mempunyai jumlah penyandang disabilitas sama yaitu kelas rendah, 0-5\% jumlah penduduk. Desa yang memiliki karakteristik kerentanan sosial ekonomi tinggi yaitu Desa Karangrejo, Kalinongko, Kalisemo dan Kebongunung. Kepadatan penduduk di desa ini tingkat sedangtinggi, jumlah keluarga yang sejahtera kelas tinggi dan kelompok umur rentan kelas sedang. Kelas kelompok umur rentan di desa ini lebih banyak dari desa lainnya sehingga mempunyai indeks kerentanan sosial ekonomi tinggi. Daerah di area yang lebih datar yaitu Desa Trirejo, Loano, Maron, Kedungpoh mempunyai indeks kerentanan sosial ekonomi sedang. Kepadatan penduduk di desa ini umumnya lebih 
dari $700 \mathrm{jiwa} / \mathrm{m}^{2}$ bahkan lebih dari $1.000 \mathrm{jiwa} / \mathrm{km}^{2}$. Keluarga kurang sejahtera kelas sedang sedangkan jumlah penduduk dengan tingkat pendidikan rendah pada kelas rendah, sehingga walaupun mempunyai kepadatan penduduk tinggi namun indeks kerentanannya tetap sedang.

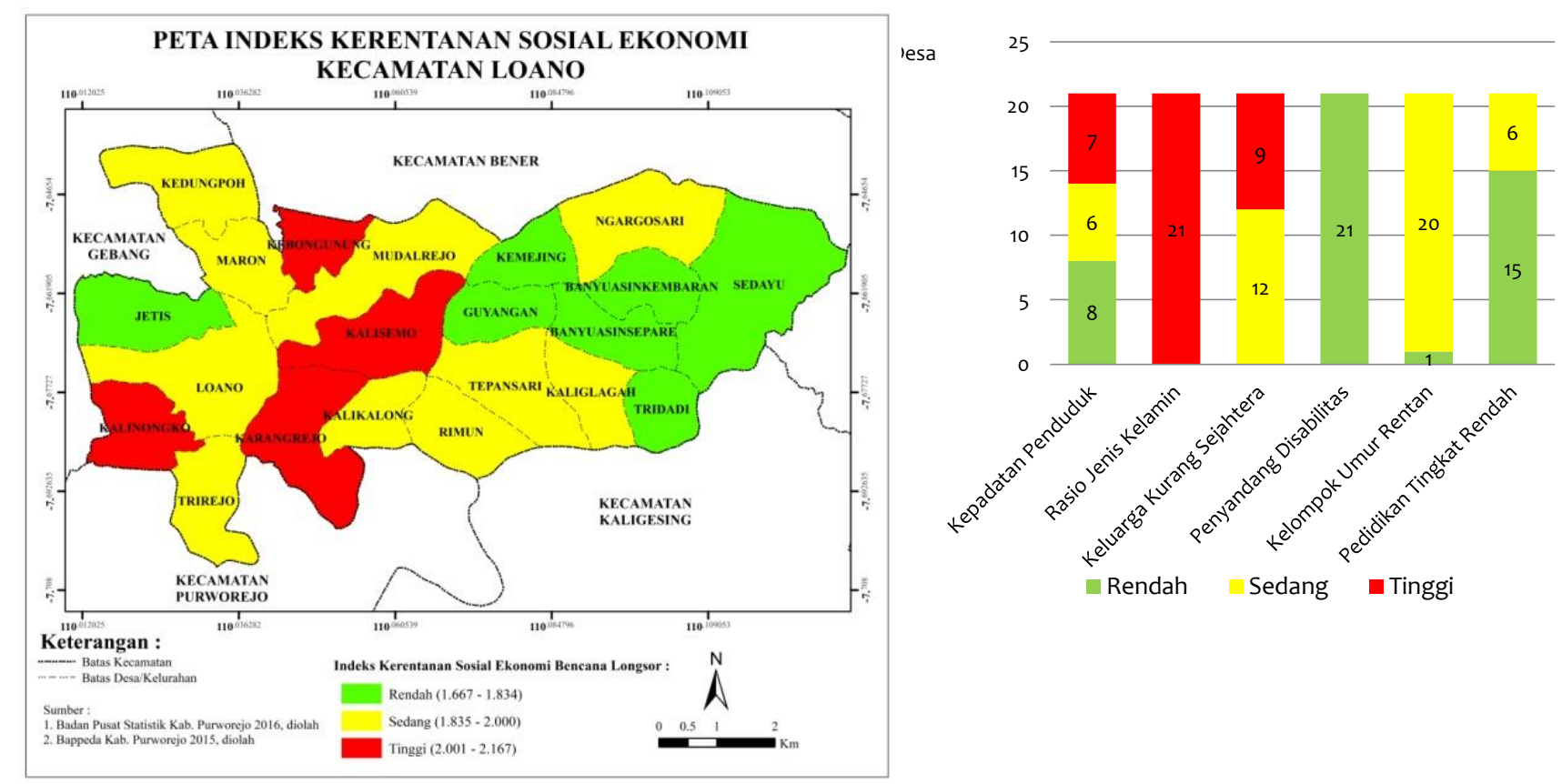

Gambar 4. Peta Indeks Kerentanan Sosial Ekonomi \& Jumlah Desa Menurut Skor Variabel (Pengolahan Data, 2018)

Desa lainnya di area sebelah timur yang mempunyai indeks kerentanan sosial ekonomi kelas sedang, antara lain Desa Kalikalong, Rimun, Tepansari, Kaliglagah dan Ngargosari. Tingkat kepadatan penduduk rendah, namun mempunyai jumlah keluarga kurang sejahtera tingkat tinggi dan jumlah penduduk dengan tingkat pendidikan rendah-sedang. Kondisi variabel saling mengimbangi sehingga kelas kerentanan sosial ekonominya sedang. Desa Jetis, Guyagan, Kemejing, Banyuasin Kembaran, Banyuasin Separe, Sedayu dan Tridadi mempunyai indeks kerentanan sosial ekonomi rendah. Karakterisitik ketujuh desa ini adalah kepadatan penduduk dan tingkat pendidikan rendah kelas rendah-sedang. Jumlah keluarga kurang sejahtera kelas 2. Berdasarkan uraian, karakteristik sebaran indeks kerentanan sosial ekonomi tidak mempunyai ciri yang sama di setiap desa. Masing-masing desa mempunyai indeks yang sama, namun belum tentu faktor pembentuknya sama.

\subsubsection{Karakteristik Kerentanan Fisik dan Lingkungan}

Karakterisik indeks dan sebaran spasial kerentanan fisik dan lingkungan sebagaimana gambar 5 . Berdasar pada gambar grafik tersebut, jumlah sekolah dan puskesmas/pustu yang ada di setiap desa masih sangat terbatas. Kelas variabel prasarana perekonomian mempunyai kelas yang bervariasi dari rendah hingga tinggi. Hampir sama dengan kelas lahan produktif yang bervariasi dari kelas rendah hingga tinggi. Kelas tinggi untuk luas lahan produktif adalah Desa Loano. Desa Loano memiliki luas sawah irigasi yang luas dibandingkan desa lainnya. Dari peta terhitung bahwa jumlah desa indeks kerentanan fisik dan lingkungan rendah sebanyak 1 desa, 7 sedang dan 13 tinggi. Desa yang mempunyai indeks kerentanan fisik lingkungan rendah adalah Desa Maron. Desa Maron berada di jalan provinsi sehingga banyak dibangun infrastruktur publik untuk mendukung aktivitas wilayah. Sehingga desa ini mempunyai kerentanan fisik lingkungan rendah. Untuk variabel luas lahan produktif, desa ini hampir sama dengan desa lainnya yang memiliki kelas sedang. 

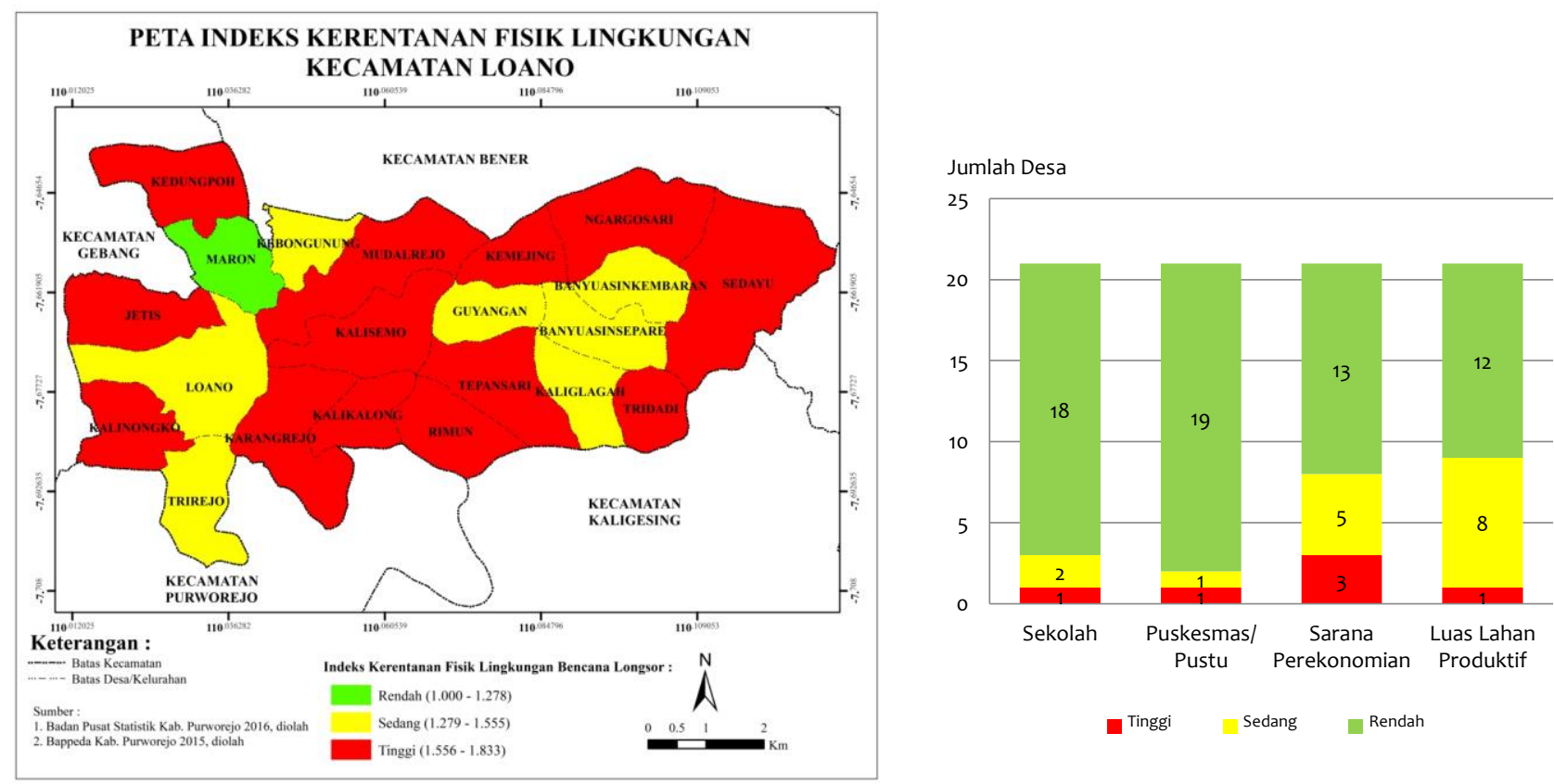

Gambar 5. Peta Indeks Kerentanan Fisik Lingkungan \& Jumlah Desa Menurut Skor Variabel (Pengolahan Data, 2018)

Desa dengan indeks kerentanan fisik lingkungan sedang yaitu Kebongunung, Loano, Trirejo, Banyuasin Kembaran, Kaliglagah dan Guyangan. Desa Trirejo, Loano dan Kebongunung, sama halnya dengan Desa Maron yang mempunyai indeks kerentanan fisik lingkungan rendah, yaitu berada pada jalur jalan lintas propinsi sehingga desanya lebih berkembang daripada desa lainnya. Desa Banyuasin Kembaran, Banyuasin Separe dan Guyangan mempunyai indeks kerentanan fisik lingkungan sedang dikarenakan memiliki jumlah fasilitas prasarana perekonomian yang lebih banyak dibandingkan dengan desa lainnya. Desa Banyuasin Kembaran merupakan pusat aktivitas kegiatan ekonomi di area timur kecamatan, sehingga prasarana kegiatan ekonominya yang banyak. Untuk karakteristik lingkungannya mempunyai jumlah luas lahan produktif rendah dibandingkan desa lainnya. Karakteristik Desa Kaliglagah mempunyai jumlah prasarana perekonomian sedang dan lahan produktif rendah sehingga indeks kerentanan fisik lingkungannya sedang. Walau dalam peta terlihat lokasi berdekatan dengan pusat ibukota kecamatan namun akses untuk menuju lokasi ini relatif sulit, karena kondisi jalan yang rusak dan lereng yang terjal. Banyaknya luas lahan produktif menjadikan indeks tinggi. Apabila terjadi bencana akan menyebabkan kerugian yang tinggi, dikarenakan penduduk yang mata pencaharian utamanya bergantung pada alam lingkungan akan kehilangan penghasilan. Disamping itu desa yang berlokasi dekat dengan pusat aktivitas akan cenderung mempunyai kerentanan fisik lingkungan yang rendah karena mempunyai akses terhadap infrastruktur publik.

\subsubsection{Karakteristik Kerentanan Sosial Ekonomi dan Fisik Lingkungan}

Kerentanan sosial ekonomi dan fisik lingkungan merupakan penggabungan antara kerentanan sosial ekonomi dan kerentanan fisik lingkungan. Nilai indeks dan sebaran keruangan sebagaimana Gambar 6 . Terdapat 3 desa dengan indeks rendah, 11 desa sedang dan 7 tinggi. Tidak ada pola khusus dalam pembentukan indeks kerentanan sosial ekonomi dan fisik lingkungan, namun kelas indeks umumnya berdekatan antara ketiga indeks yaitu kerentanan sosial ekonomi, fisik lingkungan serta sosial ekonomi \& fisik lingkungan. 


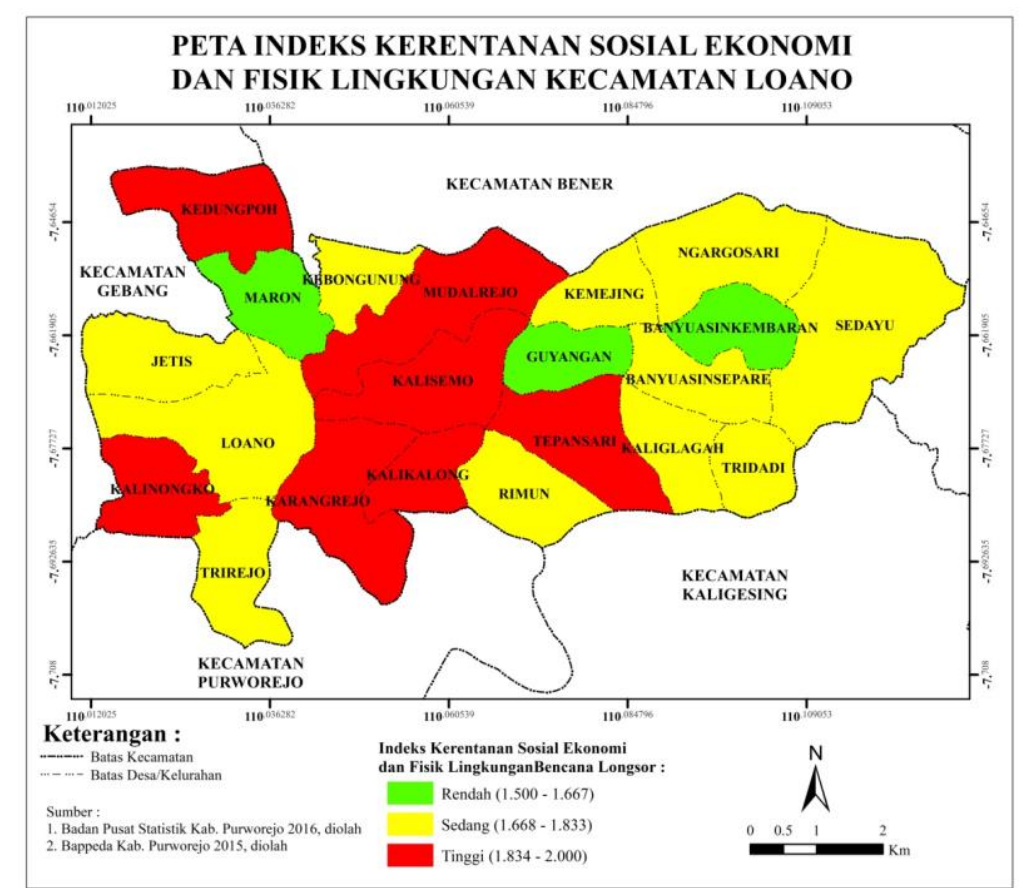

Gambar 6. Peta Indeks Kerentanan Sosial Ekonomi Dan Fisik Lingkungan (Pengolahan Data, 2018)

\subsubsection{Karakteristik Kapasitas (Respon Lingkungan)}

Hasil pengolahan kuesioner individu masyarakat dan pemerintah desa yang diambil datanya pada tanggal 12 Oktober - 7 Nopember 2017 sebagai berikut:

Tabel 4. Indeks Kapasitas (Respon Lingkungan) (Pengolahan Data Lapangan, 2018)

\begin{tabular}{clccccc}
\hline No & \multicolumn{1}{c}{ Desa } & $\begin{array}{c}\text { Jumlah } \\
\text { Responden }\end{array}$ & $\begin{array}{c}\text { Prosentase } \\
\text { Kelas 2 }\end{array}$ & $\begin{array}{c}\text { Tingkat Kapasitas } \\
\text { Masyarakat }\end{array}$ & $\begin{array}{c}\text { Tingkat } \\
\text { Kapasitas } \\
\text { Pemerintah } \\
\text { Desa }\end{array}$ & $\begin{array}{c}\text { Indeks } \\
\text { Kapasitas } \\
\text { (Respon } \\
\text { Lingkungan) }\end{array}$ \\
\hline 1 & Kalinongko & 20 & $5 \%$ & Rendah & Rendah & Rendah \\
\hline 2 & Trirejo & 25 & $16 \%$ & Rendah & Sedang & Rendah \\
\hline 3 & Karangrejo & 14 & $93 \%$ & Tinggi & Tinggi & Tinggi \\
\hline 4 & Kalikalong & 8 & $25 \%$ & Rendah & Rendah & Rendah \\
\hline 5 & Rimun & 9 & $78 \%$ & Tinggi & Sedang & Tinggi \\
\hline 6 & Tepansari & 14 & $57 \%$ & Sedang & Sedang & Sedang \\
\hline 7 & Kaliglagah & 7 & $29 \%$ & Rendah & Rendah & Rendah \\
\hline 8 & Tridadi & 9 & $11 \%$ & Rendah & Sedang & Rendah \\
\hline 9 & Banyuasin Separe & 17 & $47 \%$ & Sedang & Rendah & Rendah \\
\hline 10 & Guyangan & 7 & $71 \%$ & Sedang & Sedang & Sedang \\
\hline 11 & Kalisemo & 18 & $56 \%$ & Sedang & Tinggi & Tinggi \\
\hline 12 & Loano & 33 & $0 \%$ & Rendah & Rendah & Rendah \\
\hline 13 & Jetis & 21 & $14 \%$ & Rendah & Sedang & Rendah \\
\hline 14 & Maron & 31 & $6 \%$ & Rendah & Rendah & Rendah \\
\hline 15 & Kedungpoh & 19 & $42 \%$ & Sedang & Sedang & Sedang \\
\hline 16 & Kebon Gunung & 17 & $0 \%$ & Rendah & Rendah & Rendah \\
\hline 17 & Mudalrejo & 22 & $23 \%$ & Rendah & Sedang & Rendah \\
\hline 18 & Kemejing & 11 & $36 \%$ & Sedang & Rendah & Rendah \\
\hline
\end{tabular}




\begin{tabular}{llcccccc}
\hline No & \multicolumn{1}{c}{ Desa } & $\begin{array}{c}\text { Jumlah } \\
\text { Responden }\end{array}$ & $\begin{array}{c}\text { Prosentase } \\
\text { Kelas 2 }\end{array}$ & $\begin{array}{c}\text { Tingkat Kapasitas } \\
\text { Masyarakat }\end{array}$ & $\begin{array}{c}\text { Tingkat } \\
\text { Kapasitas } \\
\text { Pemerintah } \\
\text { Desa }\end{array}$ & $\begin{array}{c}\text { Indeks } \\
\text { Kapasitas } \\
\text { (Respon } \\
\text { Lingkungan) }\end{array}$ \\
\cline { 3 - 6 } 19 & Banyuasin Kembaran & 18 & $22 \%$ & Rendah & Rendah & Rendah \\
\hline 20 & Sedayu & 15 & $60 \%$ & Sedang & Rendah & Rendah \\
\hline 21 & Ngargosari & 10 & $30 \%$ & Rendah & Tinggi & Tinggi \\
\hline
\end{tabular}

Dari Tabel 4 diatas terlihat bahwa jarak antara indeks kapasitas masyarakat dan pemerintah saling berpasangan tidak terlalu jauh jaraknya (rendah - rendah, rendah - sedang, sedang - rendah, sedang sedang, sedang - tinggi, tinggi - sedang). Ada hubungan antara pembangunan yang dilakukan pemerintah dengan indeks kapasitas masyarakat. Semakin tinggi linking social capital, maka bridging sosial capital dan bonding social capital akan mengikuti. Sebaran keruangan kapasitas (respon lingkungan) sebagai Gambar 7.
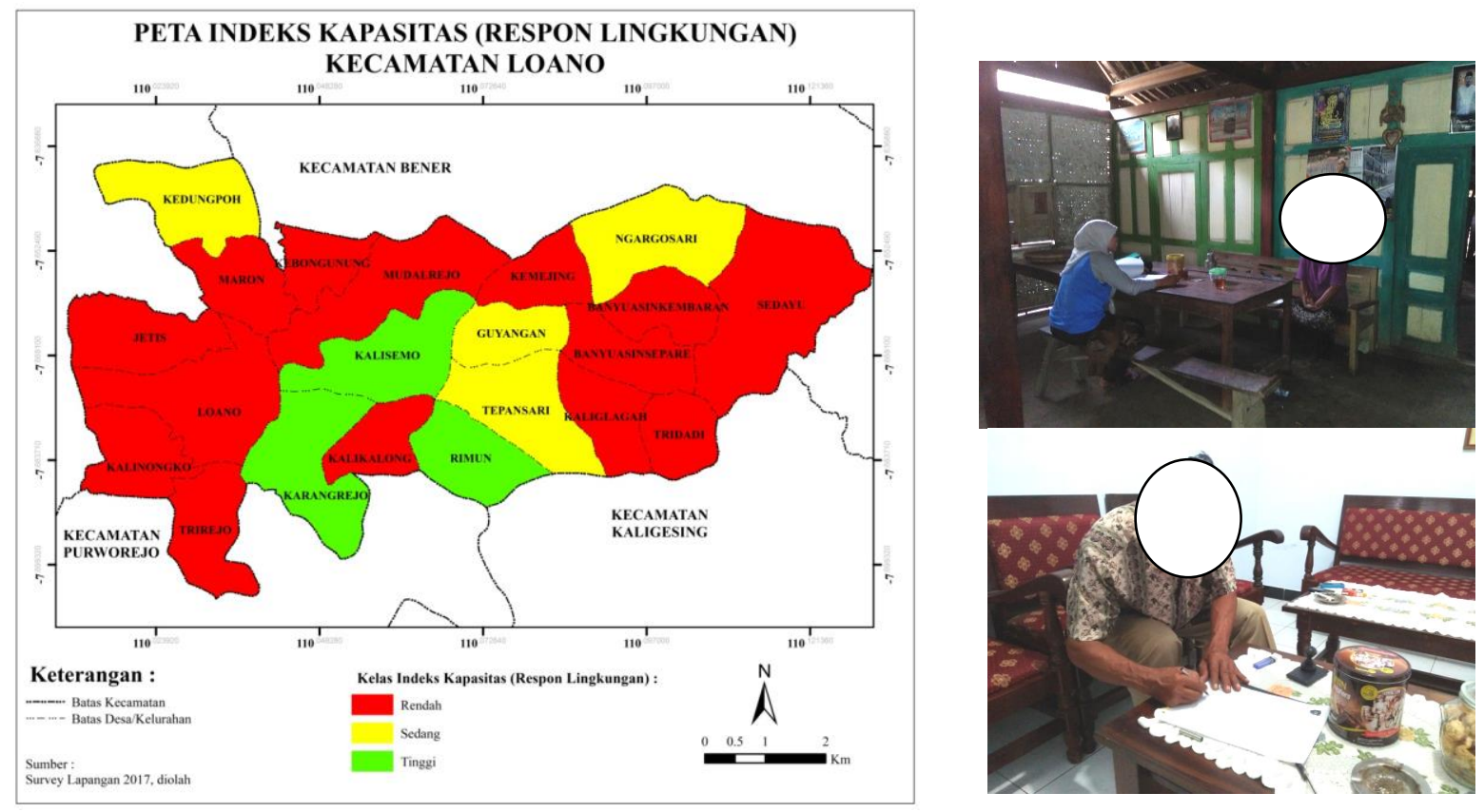

Gambar 7. Peta Indeks Kapasitas (Respon Lingkungan) \& Pengambilan Kuesioner (Pengolahan Data Lapangan, 2018; Observasi Lapangan, 2017)

\subsubsection{Kerentanan Total}

Indeks kerentanan total diperoleh dengan perpaduan antara indeks kerentanan sosial ekonomi \& fisik lingkungan dengan indeks kapasitas (respon lingkungan). Hasil perpaduan tersebut sebagaimana Gambar 8. Desa yang mempunyai indeks kerentanan rendah sebanyak 3 desa. Karakteristik ketiga desa ini adalah mempunyai indeks kapasitas (respon lingkungan) lebih tinggi daripada indeks kerentanan sosial ekonomi \& fisik lingkungannya. Ketiga daerah tersebut pernah mengalami longsor sebelumnya sehingga berpengalaman dalam menghadapi bencana dan melakukan beberapa kegiatan mitigasi bencana. Desa dengan indeks kerentanan sedang sebanyak 4 desa. Keempat desa ini mempunyai indeks kerentanan sosial ekonomi dan fisik lingkungan sama tingkatannya dengan indeks kapasitas (respon lingkungan)-nya, sehingga indeks kerentannya naik. Suatu desa harus memiliki indeks kapasitas (respon lingkungan) lebih tinggi minimal satu tingkat untuk memperoleh indeks kerentanan turun atau tetap. Sementara 14 desa lainnya mempunyai indeks kerentanan tinggi. Karakteristik desa ini memiliki kerentanan sosial ekonomi dan fisik lingkungan lebih tinggi daripada indeks kapasitas (respon lingkungan)-nya. 


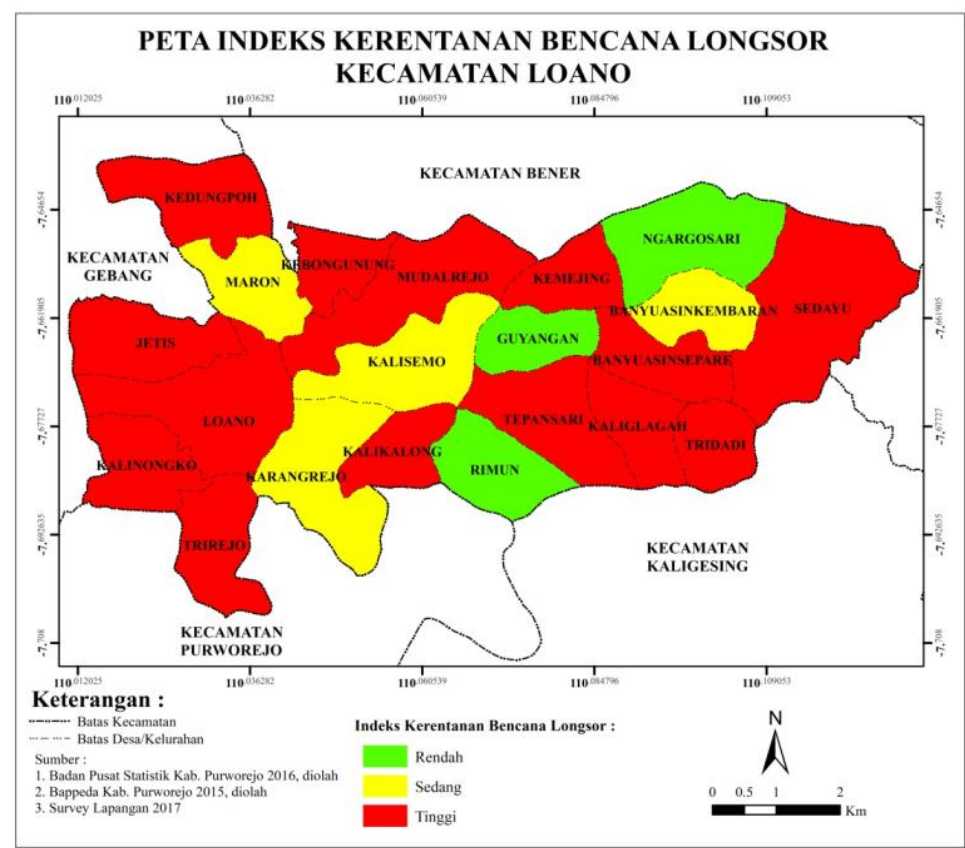

Gambar 8. Peta Indeks Kerentanan (Pengolahan Data, 2018)

\subsubsection{Tingkat Risiko Bencana Longsor}

Luas total tingkat risiko tinggi tingkat rendah adalah $6,72 \mathrm{~km}^{2}(12,62 \%)$, sedang $24,59 \mathrm{~km}^{2}(46,15 \%)$ dan tinggi $21,96 \mathrm{~km}^{2}$ (41,23\%). Sebaran keruangan tingakt risiko longsor sebagaimana Gambar 9. Tingkat risiko tinggi menyebar di Kecamatan Loano bagian timur. Luas risiko longsor lebih tinggi daripada tingkat luas ancaman alam sebagaimana Tabel 5 .
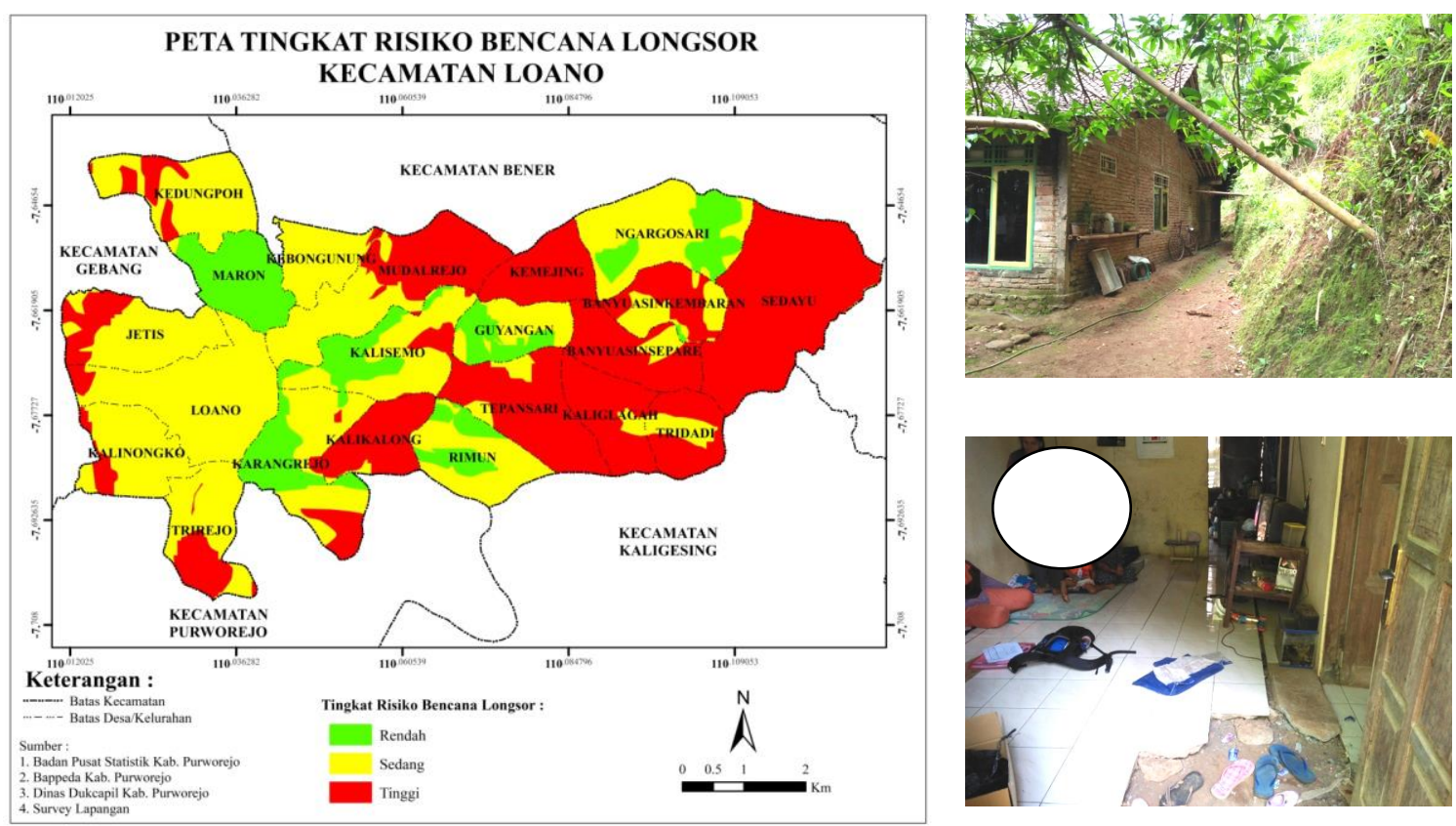

Gambar 9. Peta Tingkat Risiko Bencana Longsor Dan Masyarakat Dengan Risiko Bencana Longsor (Pengolahan Data 2018; Observasi Lapangan, 2017) 
Berdasar Tabel 5 bahwa tingkat risiko longsor bencana longsor lebih besar dari ancaman alamnya. Kondisi ini terbentuk karena masih rendahnya indeks kapasitas (respon lingkungan) sehingga kemampuan untuk menurunkan kerentanan total masih kurang dan kemampuan untuk menghadapi ancaman longsor masih perlu ditingkatkan. Banyak wilayah yang mempunyai tingkat ancaman rendah namun mempunyai tingkat risiko bencana longsor sedang karena tingginya tingkat kerentanan wilayah. Bahkan ada beberapa wilayah yang mempunyai indeks ancaman tinggi berpadu dengan tingkat kerentanan tinggi sehingga tingkat risiko bencana longsornya tinggi. Butuh perhatian besar stakeholder terkait untuk meningkatkan kapasitas (respon lingkungan) di wilayah iniContohnya adalah Desa Kemejing $100 \%$ wilayahnya mempunyai tingkat risiko bencana longsor tinggi karena indeks ancaman kelas sedang-tinggi dan kerentanan tinggi. Kerentanan Desa Kemejing ini harus dikurangi.

Tabel 5. Perbandingan Indeks Ancaman Longsor Dan Tingkat Risiko Longsor (Pengolahan Data, 2018)

\begin{tabular}{|c|c|c|c|}
\hline No. & Kelas Indeks & $\begin{array}{c}\text { Luas Indeks } \\
\text { Ancaman Longsor }\end{array}$ & $\begin{array}{l}\text { Luas Tingkat } \\
\text { Risiko Bencana }\end{array}$ \\
\hline 1. & Rendah & $21,36 \mathrm{~km}^{2}(40,09 \%)$ & $6,72 \mathrm{~km}^{2}(12,62 \%)$ \\
\hline 2. & Sedang & $13,14 \mathrm{~km}^{2}(24,66 \%)$ & $24,59 \mathrm{~km}^{2}(46,15 \%)$ \\
\hline 3. & Tinggi & $18,78 \mathrm{~km}^{2}(35,25 \%)$ & $21,96 \mathrm{~km}^{2}(41,23 \%)$ \\
\hline \multicolumn{2}{|r|}{ Total } & $53,27 \mathrm{~km}^{2}(100 \%)$ & $53,27 \mathrm{~km}^{2}(100 \%)$ \\
\hline
\end{tabular}

Desa Sedayu sebanyak $99,67 \%$ luas desanya mempunyai tingkat risiko tinggi. Sisanya merupakan indeks ancaman sedang, area ini merupakan kombinasi indeks ancaman risiko rendah berpadu dengan tingkat kerentanan tinggi. Desa ini pernah mengalami kejadian longsor dengan dampak yang relatif besar, berbeda dengan Desa Kemejing belum pernah mengalami longsor dengan dampak yang relatif besar. Indeks ancaman dan indeks risiko Desa Karangrejo dan Kalisemo dalam kelas dan luas wilayah yang sama. Desa Rimun, Guyangan dan Ngargosari yang mempunyai indeks ancaman longsor tinggi di beberapa wilayahnya, namun semua area desa tidak ada yang berisiko tinggi dikarenakan kerentanannya lebih rendah dari pada indeks ancaman longsor. Kondisi ini sangat baik dalam sebuah desa, karena beberapa peneliti berpendapat tidak mungkin mengurangi ancaman alamnya.

\section{KESIMPULAN}

Tingkat risiko bencana longsor bervariasi, mulai dari rendah, sedang hingga tinggi. Jumlah luas area risiko tingkat sedang dan tinggi hampir sama, yaitu tingkat risiko sedang sebanyak $24,59 \mathrm{~km}^{2}(46,15 \%)$ dan tinggi $21,96 \mathrm{~km}^{2}$ (41,23\%). Tingkat risiko rendah mempunyai luas kawasan relatif kecil yaitu $6,72 \mathrm{~km}^{2}$ (12,62\%). Luas risiko longsor sedang-tinggi lebih banyak daripada luas indeks ancaman longsornnya. Secara fisik alam, ancaman risiko longsor bervariasi indeksnya yaitu $21,36 \mathrm{~km}^{2}(40,09 \%)$ indeks rendah, $13.14 \mathrm{~km}^{2}$ (24,66\%) sedang dan $18,78 \mathrm{~km}^{2}$ (35,25\%) tinggi. Secara spasial daerah di sebelah timur mempunyai indeks ancaman sedang-tinggi. Lebih tinggi dari pada rata-rata indeks ancaman longsor di sebelah barat.

Kerentanan secara holistic yang merupakan jumlah total kerentanan sosial ekonomi dan fisik lingkungan serta dikurangi upaya mitigasi yang berupa kapasitas (respon lingkungan) terdapat 3 desa rendah, 4 desa sedang dan 14 desa tinggi. Desa yang mempunyai pengalaman dengan kejadian bencana sebelumnya akan mempunyai indeks kerentanan rendah-sedang. Hal ini perkecualian untuk Desa Maron dan Banyuasin Kembaran yang belum pernah pengalaman dalam bencana longsor. Tidak ada pola khusus dalam pembentukan indeks kerentanan sosial ekonomi dan fisik lingkungan. Tingkat kapasitas (respon lingkungan) dalam risiko bencana didalamnya terkandung nilai karakteristik antara individu masyarakat dan pemerintah desa yang apabila karakteristiknya baik, dapat mengurangi risiko bencana atau meningkatkan ketahanan menghadapi bencana longsor. Pada umumnya pengalaman adanya bencana di masa lampau meningkatkan karakteristik individu masyarakat dan pemerintah desa. Karakteristik pemerintah desa yang baik akan berpadu dengan karakteristik individu masyarakat yang baik, atau dapat 
dikatakan bahwa apabila suatu desa mempunyai linking social capital yang baik maka bonding social capital masyarakat desanya mengikuti baik.

Perlu dilakukan peningkatan kapasitas (respon lingkungan) dan mengurangi kerentanan variabel sosial ekonomi dan fisik lingkungan Kecamatan Loano. Hal ini dikarenakan kecamatan Loano memiliki indeks ancaman longsor tinggi. Dampak dari peningkatan kapasitas akan mengurangi jumlah korban, kerusakan serta kerugian yang terjadi apabila terjadi bencana. Pengurangan terhadap indeks ancaman hampir tidak mungkin dilakukan, sehingga yang harus diantisipasi adalah meningkatnya kerentanan serta rendahnya indeks kapasitas (respon lingkungan). Dalam rangka pengurangan kerentanan dan meningkatkan kapasitas (respon lingkungan) tentunya memerlukan upaya bersama stakeholder baik pemerintah, swasta dan masyarakat. Peningkatan kapasitas baik itu individu masyarakat maupun pemerintah desa perlu dilakukan lebih intensif, terlebih perubahan iklim yang dapat memicu terjadinya longsor. Harapan ke depan metode penelitian ini dapat diaplikasikan ke daerah lainnya yang mempunyai karakteristik wilayah yang sama dengan Kecamatan Loano. Penelitian memadukan ancaman; kerentanan sosial, ekonomi, fisik dan lingkungan serta kapasitas (respon lingkungan) sebagai suatu usaha mengkaji risiko bencana longsor yang komprehensif. Hasil kajian risiko bencana ini dapat digunakan sebagai dasar dalam perencanaan dan pengambilan kebijakan pembangunan

\section{PERNYATAAN RESMI}

Penelitian ini dilakukan dalam rangka menyelesaikan studi di Magister Pembangunan Wilayah dan Kota Universitas Diponegoro. Ucapkan terimakasih kami berikan kepada Kementerian Negara Badan Pembangunan Nasional (Pusdiklatren-Bappenas) yang telah memberikan kesempatan dan beasiswa dalam studi ini.

\section{REFERENSI}

Almeida, L. Q. De, Welle, T., \& Birkmann, J. (2016). Author's Accepted Manuscript. International Journal of Disaster Risk Reduction. https://doi.org/10.1016/j.ijdrr.2016.04.007

Arsyad. (1989). Konservasi Tanah \& Air. Bogor: IPB Press.

Badan Nasional Penanggulangan Bencana. Jumlah Kejadian Bencana 1815-2017. [Home page of Badan Nasional Penanggulangan Bencana] [Online]. Available at: http://dibi.bnpb.go.id/. Diakses pada tanggal 11 Agustus 2017.

Badan Penanggulangan Bencana Daerah Provinsi Jawa Tengah. (2017). Data Bencana Longsor Provinsi Jawa Tengah Tahun 2017. Semarang: Pusat Pengendalian Operasi Penanggulangan Bencana (PUSDALOPS) Badan Penanggulangan Bencana Daerah Provinsi Jawa Tengah.

Bappeda Kabupaten Purworejo. (2017). Data Rumah Tangga Berdasar Status Kesejahteraan Kabupaten Purworejo Tahun 2015. Purworejo.

Bemmelen, V. W. R. (1949). The Geology of Indonesia Vol. IA General Geology of Indonesia and Adjacent Archipelagoes. Netherlands: The Hague.

Coppola, D. P. (2006). Introduction International Disaster Management. Oxford: Elsevier.

Cotecchia, F., Santaloia, F., Lollino, P., Vitone, C., Cafaro, F., \& Bottiglieri, O. .(2016). A geomechanical approach to landslide hazard assessment : the Multiscalar Method for Landslide Mitigation. Procedia Engineering, 158, 452-457. https://doi.org/10.1016/j.proeng.2016.08.471

Cutter, S. L., Boruff, B. J., \& Shirley, W. L. (2003). Social Vulnerability to Environmental Hazards n. Social Science Quarterly, 84(2), 242-261. https://doi.org/10.1111/1540-6237.8402002

Dinas Pekerjaan Umum dan Penataan Ruang Kabupaten Purworejo. (2017). Data Curah Hujan Tahun 20032015. Purworejo.

Fatemi, F., Ardalan, A., Aguirre, B., Mansouri, N., \& Mohammadfam, I. . (2017). Social vulnerability indicators in disasters: Findings from a systematic review. International Journal of Disaster Risk Reduction, 22(June 2016), 219-227. https://doi.org/10.1016/j.ijdrr.2016.09.006

Frigerio, I., \& Amicis, M. De. (2016). Environmental Science \& Policy Mapping social vulnerability to natural 
hazards in Italy: A suitable tool for risk mitigation strategies. Environmental Science and Policy, 63, 187-196. https://doi.org/10.1016/j.envsci.2016.06.001

Gariano, S. L., \& Guzzetti, F. (2016). Landslides in a changing climate. Earth-Science Reviews, 162, 227-252. https://doi.org/10.1016/j.earscirev.2016.08.011

Hardiyatmo, C. (2012). Tanah Longsor \& Erosi Kejadian dan Penangannya.Yogyakarta: Gadjah Mada University Press.

Karnawati, D. (2005). Bencana Alam Gerakan Massa Tanah di Indonesia dan Upaya Penanggulangannya. Yogyakarta: Jurusan Teknik Geologi Fakults Teknik Universitas Gadjah Mada.

Karnawati, D., Fathani, T. F., Andayani, B., Burton, P. W., \& Sudarno, I. (2009). Strategic program for landslide disaster risk reduction: A lesson learned from Central Java, Indonesia. WIT Transactions on the Built Environment, 110, 115-126. https://doi.org/10.2495/DMANog0121

Kiyoung, J. K., \& Kim, S. Y. (2018). Assessing regional typhoon risk of disaster management by clustering typhoon paths. Environment, Development and Sustainability. https://doi.org/10.1007/s10668-0180086-2

Kwabena, E., Boakye-danquah, J., Barima, A., Ko, S., Mensah, R., Agyeman, Y., \& Toloo, P. (2015). Community vulnerability assessment index for $\mathrm{fl}$ ood prone savannah agro-ecological zone : A case study of Wa West District, Ghana, 10, 56-69. https://doi.org/10.1016/j.wace.2015.10.008

Palladino, M. R., Viero, A., Turconi, L., Brunetti, M. T., Peruccacci, S., Melillo, M., ... Guzzetti, F. (2017). Geomorphology Rainfall thresholds for the activation of shallow landslides in the Italian Alps: the role of environmental conditioning factors. Geomorphology, 303, 53-67. https://doi.org/10.1016/j.geomorph.2017.11.009

Pinkowski, J. (2008). Disaster management handbook. Boca Raton: CRC Press.

Raghuvanshi, T. K., Ibrahim, J., \& Ayalew, D. (2014). Journal of African Earth Sciences Slope stability susceptibility evaluation parameter ( SSEP ) rating scheme - An approach for landslide hazard zonation. Journal of African Earth Sciences, 99, 595-612. https://doi.org/10.1016/j.jafrearsci.2014.05.004

Shari, A., \& Yamagata, Y. (2016). International Journal of Disaster Risk Reduction On the suitability of assessment tools for guiding communities towards disaster resilience, 18, 115-124. https://doi.org/10.1016/j.ijdrr.2016.06.006

Xiaoyan, D. U., \& Xiaofei, L. I. N. (2012). 2012 International Symposium on Safety Science and Technology Conceptual model on regional natural disaster risk assessment, 45, 96-100. https://doi.org/10.1016/j.proeng.2012.08.127 , (2016). Risiko Bencana Indonesia 2016. Badan Nasional Penanggulangan Bencana, 2016.

, (2012). Peraturan Kepala Badan Penanggulangan Bencana No. 2 Tahun 2012 tentang Pedoman Umum Pengkajian Risiko Bencana. 